И. Н. Воротынцев [Ig. N. Vorotintcev]

\title{
МЕХАНИЗМЫ ОБЕСПЕЧЕНИЯ ПОЛИТИКИ НАЦИОНАЛЬНОЙ БЕЗОПАСНОСТИ В СИТУАЦИИ НОВЫХ УГРОЗ И ВЫЗОВОВ: КОМПАРАТИВИСТСКИЙ АНАЛИЗ
}

\author{
MECHANISMS OF NATIONAL SECURITY POLICY ENSURING IN A SITUA- \\ TION OF NEW THREATS AND CHALLENGES: A COMPARATIVIST ANALY- \\ SIS
}

Института сервиса, туризма и дизайна (филиал) «Северо-Кавказский федеральный университет», г. Пятигорске, Россия, г. Пятигорск, е-mail: ivorotyncev@mail.ru

\begin{abstract}
Аниопация. Национальнал безопасность трактуется в качестве системы способов, средств и ииституциональныш форм реализации национальных интересов во внутренней и внеиней политике, защищённости государства, общества и граждан от рисков и угроз.

Материаль, методы, результаты и обсуждения. Традиционнье направления политики национальной безопасности - защита конституционного строя государспва, его суверенитета и территориальной целостности в условиях глобализации дополнень новыми направлениями: антитеррористической и антиэкстремистской политикой, противодействием международной организованной преступности, обеспечением информачионной безопасности. $B$ данной статье автор сравнивает механизмы обеспечения политики национальной безопасности двух систем.

Ннституциональная подсистема обеспечения политики национальной безопасности РФ становится более разветвленной и организационно рациональной. При сохранении стратегического руководства Президента РФ и Совета безопасности РФ на уровне спечиализированных органов возросла роль Начионального антитеррористического комитета,

антитеррористических комиссий субъъектов федерации. Система обеспечения национальной безопасности РФ силу специфики территориальных политических рисков и угроз включает в себя федеральный, макрорегиональньй, региональньй и муниципальный уровни. На макрорегиональном (федеральнье округа) и региональном (субъектьы федерации) уровнях необходимы програлиь реализации Стратегии национальной безопасности РФ.

Заключение. Таким образом, национальная безопасность РФ является многоуровневой по субъектал реализации. В этой связи важно учитывать разграничение предметов веденил и полномочий в сфере национальной безопасности между федеральньми и региональньми органали власти РФ.
\end{abstract}

Ключевые слова: национальная безопасность, государственная безопасность, концепция национальной безопасности, доктрина информационной безопасности, сепаратизи, сецессия, экстремизм, угрозы и риски государства.

Abstract. National security is interpreted as a system of methods, means and institutional forms for the realization of national interests in domestic and foreign policy, protection of the state, society and citizens from risks and threats.

Materials, methods, results and discussions. The traditional directions of national security policy - protection of the constitutional system of the state, its sovereignty and territorial integrity in the context of globalization - have been supplemented with new directions: anti-terrorist and anti-extremist policies, countering international organized crime, ensuring information security. In this article, the author compares the mechanisms for ensuring the national security policy of the two systems. The institutional subsystem for ensuring the national security policy of the Russian Federation is becoming more ramified and organizationally rational. While maintaining the strategic leadership of the President of the Russian Federation and the Security Council of the Russian Federation at the level of specialized bodies, the role of the National Antiterrorist Committee and the antiterrorist commissions of the subjects of the Federation has increased. The system of ensuring the national security of the Russian Federation, due to the specifics of territorial political risks and threats, includes the federal, macro regional, regional and municipal levels. At the macro regional (federal districts) and regional (federal subjects) levels, programs for the implementation of the RF National Security Strategy are required.

Conclusion. Thus, the national security of the Russian Federation is multi-level in terms of subjects of implementation. In this regard, it is important to take into account the division of responsibilities and powers in the field of national security between Federal and regional authorities of the Russian Federation.

Key words: national security, state security, concept of national security, doctrine of information security, separatism, secession, extremism, threats and risks of the state.

Введение. До распада СССР в отечественном законодательстве и паучной литературе доминировало использование термина «государственная безопасность», с которым «национальная безопасность» отождествлялась. Тем самым, реализовывался принцип верховенства интересов социалистического государства над интересами личности. В нормативно-правовом аспекте термин стал широко употребляться после создания Главного управления государственной безопасности в структуре Народного комиссариата внутренних дел СССР (1934 
г.). Понятие «государственная безопасность» не конкретизировалось, хотя и вошло в ст. 14 п. «и» Конституции CCCP $1936 \Gamma^{4}$.

Первая попытка разработать концепцию национальной безопасности страны в условиях демократии состоялась в мае 1990 г., когда группа Комитета Верховного Совета СССР по науке, народному образованию, культуре и воспитанию под руководством Ю.А. Рыжова подготовила проект концепций. Он впервые определял национальную безопасность как органическое единство безопасности личности, общества и государства. Причём основой была названа безопасность личности, которая определяет безопасность гражданского общества и легитимность правового государства. Авторы законопроекта обосновывали реализацию безопасности в двух измерениях: общественном и государственном. По источникам угроз, опасностей и рисков для жизненно важных интересов безопасность классифицировалась на внутреннюю и внешнюю. Авторы проекта концепции впервые обращали внимание политического руководства страны на то, что ведущие угрозы безопасности возникают в сфере внутренней политики, и это требует коренного пересмотра целей и механизмов обеспечения безопасности. Увы, «война законов» между союзным и российским центрами власти в 1990-1991 гг., идейнополитическая неготовность правящей элиты, распад СССР не позволили принять концепцию.

Материалы, методы, результаты и обсуждения. С образованием Российской Федерации как независимого государства разрабатывается Закон РФ «О безопасности», введённый в действие Постановлением Верховного Совета страны 5 марта 1992 г. ${ }^{6}$ Его ст. 1 определила безопасность как «состояние защищённости жизненно важных интересов личности, обшества и государства от внутренних и внешних угроз». Как справедливо оценивает эту формулировку один из тогдашних российских депутатов В.Л. Шейнис, она соответствовала демократическому правосознанию и конституционному принципу - высптей ценности человека, его прав и свобод?. Основными принципами обеспечения безопасности впервые были выбраны: законность; соблюдение баланса жизненно важных интересов личности, обшества и государства; их взаимная ответственность по обеспечению безопасности; интеграцию национальной системы безопасности с международными. Указанный закон впервые сформулировал и легитимировал правовую систему обеспечения национальной безопасности РФ, установил её функции, субъектов, силы и средства обеспечения. Был определен порядок организации и ресурсов сил обеспечения безопасности, контроля и надзора над законностью их действий.

Вместе с тем, становление российской концепции национальной безопасности шло при острых копфликтах ценностей и интересов. Так, в условиях децентрализованного и этнизированного федерализма 1990-х гг. ряд политиков критиковали сам термин «национальная» безопасность. Разработчики закона вынуждены были пояснять, что речь идёт о синонимах «национально-государственной» и «об̆щей» безопасности России ${ }^{8}$. В.Л. IШейнис признает: закон 1992 г. был «возможно, несколько декларативным, оперировавшим не вполне раскрытыми понятиями и недостаточно детализованным», хотя и прогрессивным'. Не удалось и намерение в $1992-$ 1993 гг. принять первую Концепцию национальной безопасности РФ. Она пе была утверждена Президентом страны (по сообщениюо С.В. Кортунова) ${ }^{10}$. До середины 1990-х гг. шли острые дискуссии о применимости самих категорий «пациональные интересы» и «национальная безопаспость». ${ }^{11}$

Следуюший шаг в институционализации концепции национальюой безопасности России был совершён только через три года, в Послании по национальной безопасности Президента Российской Федерации Федеральному Собранию РФ $1996 r^{12}$. Смысл категории «национальная безопасность» был концептуально расширен: «Обеспечение безопасности должно быть направлено не только на предотвращение угроз, но и на осуществление комплекса мер по развитию и укреплению прав и свобод личности, материальных и духовных цепностей общества, конституционного строя, суверенитета и территориальной целостности государства» ${ }^{13}$.

Другой ключевой концепт - национальные интересы России стали трактоваться в двойственном (государственном и общественном) смысле: как коснова формирования стратегических задач впутреншей и внешшей политики страны» и«интегрированпое выражение жизненпо важных интересов личности, общества, государ-

\footnotetext{
4 Линдер И. Б., Чуркин С. А. История специальных служб России Х-ХХ веков. М., 2005. С. 717

${ }_{5}^{5}$ Вахрамеев А. В. К вопросу об обеспечении национальной безопасности Российской Федерации // Социальногуманитарные знания. 2001. №1. С. 14.

6 Закон РФ «О безопасности» от 5 марта 1992 г. №2446-1 // Российская газета. 1992. 9 марта.

${ }^{7}$ Шейнис В. Л. Национальная безопасность России. Испытание на прочность // Полис. 2009. №5. С. 143.

${ }^{8}$ Казакова М. Н. Эволюция политико-правовых основ национальной безопасности Российской Федерации // Модернизация и политика: традиции и перспективы России. Политическая наука: Ежегодник 2011. М., 2011. С. 411.

${ }^{9}$ ПТейнис В. Л. Указ. соч. С. 142.

${ }^{10}$ Стенограмма «круглого стола» «Национальная безопасность России: доктрина и реальность» // Политическая экспертиза. Альманах. СПб., 2005. Вып. 2. С. 277.

${ }^{11}$ Сорокин К. Э. Государственные интересы как обобцение национальных // Полис. 1995. №1. С. 114-120; Капустин Б. Г. «Национальный интерес» как консервативная утопия // Свободная мысль. 1996. №3. С. 13-38; Концепция национальных интересов: общие параметры и российская специфика (материалы кругл. стола) // Мир. экономика и междунар. отношт. 1996. №7. С. 59-69; №8. С. 78-84; №9. С. 69-82.

12 Послание по национальной безопасности Президента РФ Федеральному Собранию 13.06.1996 // Независимая газета 1996. 14 июня.

${ }^{13}$ Там же
}

138 Выпуск №2, 2020 
ства» ${ }^{14}$. В Послании 1996 г. впервые предпринята попытка определить основные долгосрочные интересы страны: «Их суть сводится к тем содержательным блокам: процветание народа, защита и обустройство территории его проживания и развитие национальной культуры» ${ }^{15}$.

В 1997 г. принимается Концепция национальной безопасности Российской Федерации. Она более отчётливо, чем предшествующие акты, определила систему национальных интересов РФ в области экономики, во внутриполитической, международной, оборонной и информационной сферах, социальной сфере, духовной жизни и культуре ${ }^{16}$. Концепция добавила к перечислению интересов личности, общества и государства их сбалансированность (в отличие от акцента в начале 1990-х гг. на интересах личности).

Качественно иной этап стратегического проектирования политики национальной безопасности наступил в РФ осенью 1999 г. в контексте курса консолидации государства, усиления его внутри- и внепнеполитических позиций. Реформированная нормативно-правовая основа национальной безопасности России в начале 2000-х гг. определена в следуюших документах:

- «Концепции национальной безопасности Российской Федерации» (в редакции Указа Президента РФ от 10 января 2000 г.) $)^{17}$;

- «Доктрине информационной безопасности Российской Федерации», утвержденной Указом Президента РФ 9 сентябрря $2000 \Gamma^{18}$; $2000 \Gamma^{19}$

- Военной доктрине 2000 г., утвержденной Указом Президента Российской Федерации от 21 апреля

- «Основах пограничной политики РФ», утвержденных Указом Президента РФ 5 октября 1996 г. $^{20}$;

- «Концепции приграничного сотрудничества в Российской Федерации», утвержденной распоряжением Правительства РФ 9 февраля 2001 г. $^{21}$

Сравним основные параметры концептуального проектирования политики национальной безопасности в Концепции 2000 г. и Стратегии 2009 г.

Согласно Концепции национальной безопасности РФ в редакции 2000 г., внутриполитические аспекты национальной безопасности таковы: поддержание единства и целостности государства, обеспечение баланса потенциалов и интересов регионов, недопущение сепаратизма и сецессии ${ }^{22}$. Безопасность должна обеспечивать оптимальное сочетание жизненно важных интересов общества, государства и личности на основе принципов законности.

Концепция национальной безопасности РФ трактовала национальные интересы России как совокупность сбалансированных интересов личности, общества и государства в экономической, внутриполитической, социальной, международной, информационной, военной, пограничной, экологической и других сферах. Национальныс интересы долгосрочны. Они определяют основныс цели, стратегические и текущие задачи внутренней и внешней политики государства.

Специфика пациональных интересов России (по Д. В. Кротову) ${ }^{23}$ в том, что они определяются базовыми параметрами состояния страны: её обеспечением природными и экономическими ресурсами, социальной структурой населения, политической системой, типом политической культуры и идентичности, характером внешних и внутренних угроз безопасности.

Политический аспект национальных интересов включает в себя обеспечение гарантий конституциопного строя страны, её суверенитета и территориальной целостности, гражданского мира и национального согласия, единства правового пространства. Необходимо также нейтрализовать причины и условия политичсского и религиозного экстремизма, этносепаратизма, последствиями которых становятся насильственные конфликты.

Осповные задачи обеспечения национальной безопасности РФ таковы:

- своевременное прогнозирование и выявление угроз национальной безопасности;

${ }^{14}$ Там же.

15 Там же.

${ }^{16}$ Концепция национальной безопасности Российской Федерации (утверждена Указом Президента РФ 17 декабря 1997 г., №1300) // Российская газета. 1997. 18 дек.

${ }^{17}$ Концепция национальной безопасности Российской Федерации (в редакции Указа Президента РФ от 10 января 2000 г., №24) // Российская газета. 2000. 18 янв.

18 Доктрина информационной безопасности Российской Федерации (утверждена Указом Президента РФ 9 сентября 2000 г. №1895-Пр) // Российская газета. 2000. 28 сент.

${ }_{19}^{19}$ Военная доктрина Российской Федерации: У тверждена Указом Президента Российской Федерации от 21 апреля 2000 г. №706. Режим доступа: http://www.rg.ru/oficial/doc/ykazi/doc_war.htm

${ }^{20}$ Основы пограничной политики Российской Федерации: Утверждены Президентом РФ 5 окт. 1996 г. // Российская газета. 1996. 14 окт.

${ }^{21}$ Концепция приграничного сотрудничества в Российской Федерации: Утверждена распоряжением Правительства РФ от 9 февр. 2001 г. // Российская газета. 2001. 16 февр.

${ }_{22}^{23}$ Концепция национальной безопасности Российской Федерации // Российская газета. 2000, 18 янв.

${ }^{23}$ Кротов Д. В. Политическая безопасность России (на материалах Южного федерального округа) // Национальная и региональная безопасность на Юге России: новые вызовы. Ростов н/Д, 2003. С. 102. 
угроз;

- осуществление тактических и стратегических мер по предупреждению и нейтрализации данных

- обеспечение суверенитета и территориальной целостности России, безопасности её пограничного пространства;

- обеспечение личной безопасности человека и гражданина, его конституционных прав и свобод в пространственном аспекте (равенства прав на всей территории страны, свобода выбора места жительства и пребывания);

- совершенствование системы государственной власти РФ, федеративных отношений, местного самоуправления и законодательства РФ;

- сохранение социально-политической стабильности общества;

- формирование гармоничных межэтнических отношений;

- подъем и поддержание на необходимом уровне обороноспособности военного потенциала государства.

Концепция национальной безопасности РФ (2000г) определяла специализированные направления обеспечения безопасности. В конституционно-правовой сфере направлениями, имеющими политический характер, указывались ${ }^{24}$ :

- обеспечение приоритета федерального законодательства;

- разработка организационных и правовых механизмов защиты государственной целостности, обеспечение сдинства правового пространства;

- выработка и реализация политики, обеспечивающей оптимальный баланс федеральных и региональных интересов;

- пресечение деятельности партий и обшественных объединений, имеющих сепаратистские цели;

- правовая защита культурного наследия, историчсских традиций и духовных норм жизни всех народов РФ; сохранение роли русского языка как фактора духовной интеграции народов РФ;

- применение воснной силы внутри территории страны в строгом соответствии с Конституцией РФ и федеральными законами в случаях возникновения угрозы жизни граждан, территориальной целостности страны, угрозы насильственного изменения конституционного строя.

Основные приоритеты обеспечения национальной безопасности России в сфере её внутренней политики не формулируются в упомянутой Концепции концентрированно. По работам Ю. В. Морозова, К. В. Сивкова, М. Н. Казаковой ${ }^{25}$ можно выделить приоритетныс направления:

- защиту территориальной целостности, противодействие сепаратизму;

- создание и поддержание устойчивых эффективных отношений между центром и регионами на основе комплекса экономических, правовых и политических мер;

- предупреждение насильственшых форм межэтнических и межконфессиональных конфликтов, управление существующими конфликтами в целях их урегулирования;

- проведение информационной и, шире, символической политики, направленной на укрепление общероссийской идентичности и толерантности;

- восстановление ресурсов Вооруженных сил и правоохранительных органов, необходимых для реализации задач национальной безопасности;

- курс «территориальной справедливости» в политике, призванный обеспечить равенство возможностей граждан РФ независимо от места их жительства, этничности, конфессии и иных социально значимых различий:

- пограничное взаимовыгодное сотрудничество на равноправной основе с зарубежными странами и транснациональным организациями.

В политической науке разработап ряд важшых терминов, которые недостаточно отражены в федеральных правовых актах. К ним относится категория «источник опасности». А. А. Сергунин определяет источники в качестве условий и факторов, которые обнаруживагот свои вредоносные свойства. Опасность - «осознаваемая, но не фатальная вероятность причинения вреда..., определяемая наличием неких объективных и су бъективных факторов) ${ }^{26}$. По степени вероятности опасность подразделяется на реальную и потенциальную. Меньшими по масштабам негативного воздействия на страну являются риски и вызовы. Риск безонасности трактуется международниками А. А. Сергуниным и А. С. Макарычевым узко - как возможность неблагоприятных и нежелательных последствий деятельности именно субъекта безопасности (государства либо отдельного органа власти). ${ }^{27}$ Напротив, специалисты по внутриполитическим аспектам расширяют понятие «риск безопасности». С. А. Красиков определяет его как коллективный риск, связанный со столкновением множества групповых политических

${ }^{24}$ Концепция национальной безопасности Российской Федерации // Российская газета. 2000, 18 янв.

${ }^{25}$ Морозов Ю. В., Сивков К. В. Стратегические подходы к реализации геополитических интересов России в XXI веке // Вызовы безопасности и зацита геополитических интересов России. М., 1999. С. 41-42, 49-50; Казакова М. Н. Политико-территориальные аспекты национальной безопасности России в условиях политической трансформации в постсоветский период. Автореф. дис. ... канд. полит. наук. Н. Новгород, 2004. С. 19.

${ }^{26}$ Сергунин А. А. Международная безопасность: новые подходы и концепты // Полис. 2005. №6. С. 127.

27 Там же; Макарычев А. С. «Мягкие» и «жёсткие» вызовы безопасности в Приволжском федеральном округе: Аналитический доклад. Н. Новгород, 2001. С. 15-24.

140 Выпуск №2, 2020 
интересов, с рядом затропутых последствиями субъектов, имеющий системный характер, затрагивающий все сферы общества. Это вынужденный, некалькулируемый риск с неопределенным временем последствий ${ }^{28}$.

Вызов безопасности обычно трактуется в качестве совокупности обстоятельств, воздействующих на государство извне, не обязательно угрожающего характера, но требующих ответной реакции субъекта безопасности.

В 2000 г. впервые была концептуально выделена сфера информационной безопасности, которая стала пониматься отныне не в узком смысле защиты личности, общества и государства от информационных угроз, а в широком: политико-идеологическом. Характерно упоминание в тексте «Доктрины информационной безопасности РФ» 2000 г. таких угроз, как «монополизация информационного рынка России, его отдельных секторов отечественными и зарубежными информационными структурами». Справедливо подчеркнута опасность «девальвации духовных ценностей, пропаганды образцов массовой культуры, основанных на культе насилия, на духовных и нравственных ценностях, противоречаших ценностям, принятым в российском обшестве» ${ }^{29}$.

Субъекты политики России и их функции, согласно Концепции национальной безопасности 2000 г., выполняют следующие законные функции ${ }^{30}$.

Президент РФ руководит в пределах конституционных полномочий государственными органами обеспечения национальной безопасности, возглавляет Совет безопасности РФ и руководит его повседневной деятельностью, определяет стратегию обеспечения безопасности, санкционирует действия по её реализации. Он формирует, реорганизует и упраздняет подчиненные органы и силы обеспечения безопасности. В ежегодных посланиях Федеральному Собранию Президент страны уточняет положения Концепции (с 2009 г. - Стратегии) национальной безопасности РФ, определяет направления текущей внутренней и внешней политики в данной cфepe.

Федеральное собрание РФ по представлению Президента РФ Правительства страны формирует законодательную базу в области обеспечения национальной безопасности.

Правительство РФ в пределах своих полномочий и с учетом приоритетов обеспечения национальной безопасности координирует деятельность федеральных органов исполнительной власти, органов исполнительной власти субъектов РФ. Оно формирует статьи федерального бюджета для реализации целевых программ в данной сфере.

Совет Безопасности РФ проводит упреждающее выявление и оценивает угрозы национальной безопасности, готовит проекты решений по их предотвращению и предложения в области обеспечения национальной безопасности. Координирует реализацию федеральными и региональными органами исполнительной власти данных решений.

Федеральные органы исполнительной власти исполняют законодательство РФ, решения Президента РФ и Правительства РФ в области национальной безопасности, разрабатывагот законопроекты и представляют их на голосование законодательным органам.

Органы исполнительной власти субъектов РФ взаимодействуют по вопросам исполнения законодательства РФ, решений Президента РФ и Правительства страны, федеральных программ и планов, директив Верховного Главнокомандующего Вооруженными силами РФ с федеральными органами исполнительной власти. Совместно с органами местного самоуправления привлекают граждан, общественные объединения и организации к содействию в решении задач национальной безопасности. Они вносят в федеральные органы исполнительной власти предложения по совершенствованию системы обеспечения национальной безопасности РФ.

Заключение. Таким образом, национальная безопасность РФ является многоуровневой по субьектам pеализации. В этой связи важно учитывать разграничение предметов ведения и полномочий в сфере национальной безопасности между федеральными и региональными органами власти Р $\Phi^{31}$.

\section{ЛИТЕРАТУРА}

1. Линдер И. Б., Чуркин С. А. История специальных служб России Х-ХХ веков. М., 2005. С. 717.

2. Вахрамеев А. В. К вопросу об обеспечении национальной безопасности Российской Федерации // Социальногуманитарные знания. 2001. №1. С. 14

3. Закон РФ «О безопасности» от 5 марта 1992 г. №2446-1 // Российская газета. 1992.9 марта.

4. ІПейнис В. Л. Национальная безопасность России. Испытание на прочность // Полис. 2009. №5. С. 143.

5. Казакова М. Н. Эволюция политико-правовых основ национальной безопасности Российской Федерации // Модернизация и политика: традиции и перспективы России. Политическая наука: Ежегодник 2011. М., 2011. С. 411.

6. Стенограмма «круглого стола» «Национальная безопасность России: доктрина и реальность» // Политическая экспертиза. Альманах. СПб., 2005. Вып. 2. С. 277.

${ }^{28}$ Красиков С. А. Управление социально-политическим рисками в условиях глобализации. Автореф. дис.... Д-ра полит. наук. Н. Новгород, 2009. С. 25-27.

29 Локтрина информационной безопасности Российской Федерации (утверждена Президентом РФ от 9 сентября 2000 г. №Пр-1895) // Российская газета. 2000. 28 сент.

${ }^{30}$ Концепция национальной безопасности Российской Федерации // Российская газета. 2000, 18 янв.

${ }^{31}$ Сергунин А. А. Правовое регулирование международной деятельности субъектов Российской Федерации // Конституционное право: восточноевропейское обозрение. 2002. №1. С. 183-190. 
7. Сорокин К. Э. Государственные интересы как обобщение национальных // Полис. 1995. №1. С. 114-120; Капустин Б. Г. «Национальный интерес» как консервативная утопия // Свободная мысль. 1996. №3. С. 13-38.

8. Послание по национальной безопасности Президента РФ Федеральному Собранию 13.06.1996// Независимая газета 1996. 14 июня.

9. Концепция национальной безопасности Российской Федерации (утверждена Указом Президента РФ 17 декабря 1997 г., №1300) // Российская газета. 1997. 18 дек.

10. Концепция национальной безопасности Российской Федерации (в редакции Указа Президента РФ от 10 января 2000 г., №24) // Российская газета. 2000. 18 янв.

11. Доктрина информационной безопасности Российской Федерации (утверждена Указом Президента РФ 9 сентября 2000 г. №1895-Пр) // Российская газета. 2000. 28 сент.

12. Военная доктрина Российской Федерации: Утверждена Указом Президента Российской Федерации от 21 апреля 2000 г. №706. Режим доступа: http://www.rg.ru/oficial/doc/ykazi/doc_war.htm

13. Основы пограничной политики Российской Федерации: Утверждены Президентом РФ 5 окт. 1996 г. // Российская газета. 1996. 14 окт.

14. Концепция приграничного сотрудничества в Российской Федерации: Утверждена распоряжением Правите.ाьства РФ от 9 февр. 2001 г. // Российская газета. 2001. 16 февр.

15. Концепция национальной безопасности Российской Федерации // Российская газета. 2000, 18 янв.

16. Кротов Д. В. Политическая безопасность России (на материалах Южного федерального округа) // Национальная и региональная безопасность на Юге России: новые вызовы. Ростов н/Д, 2003. С. 102.

17. Морозов IО. В., Сивков К. В. Стратегические подходы к реализации геополитических интересов России в XXI веке // Вызовы безопасности и защита геополитических иштересов России. М., 1999. С. 41-42.

18. Сергунин А. А. Международная безопасность: новые подходы и концепты // Полис. 2005. №6. С. 127.

19. Красиков С. А. Управление социально-политическим рисками в условиях глобализации. Автореф. дис....д-ра полит. наук. Н. Новгород, 2009. С. 25-27.

20. Доктрина информационной безопасности Российской Федерации (утверждена Президентом РФ от 9 сентября 2000 г. №Пр-1895) // Российская газета. 2000. 28 сент.

21. Концепция национальной безопасности Российской Федерации // Российская газета. 2000,18 янв.

22. Сергунин А. А. Правовое регулирование международной деятельности субъъектов Российской Федерации // Конституционное право: восточноевропейское обозрение. 2002. №1. С. 183-190.

\section{OБ ABTOPE | ABOUT AUTHOR}

Воротынщев Игорь Николаевич, соискатель кафедры истории и философии права Института сервиса, туризма и дизайна (филиал) «Северо-Кавказский федеральный университет», г. Пятигорске. 357500, г. Пятигорск, пр. 40 лет Октября, 56. Tel.8906-468-33-80, e-mail: ivorotyncev@mail.ru Vorotintcev Igor Nikolaevich, Competitor of the Department of History and Philosophy of Law Institute of service, tourism and design (branch) "North-Caucasian Federal University", Pyatigorsk, 357500, Pyatigorsk, pr. 40 October, 56. Tel.8906-468-33-80, e-mail: ivorotyncev@mail.ru 